\title{
EXAMINING THE DEVELOPMENT OF CREATIVITY IN ADOLESCENTS IN 9TH AND 12TH GRADES: A FOUR-YEAR LONGITUDINAL STUDY
}

\author{
Güneş SALI ${ }^{*}$ \\ Yozgat Bozok University, Faculty of Education, Department of Educational Science, \\ Atatürk Yolu 7. km 66100 Merkez/Yozgat, Turkey
}

Received 28 April 2019; accepted 29 September 2019

\begin{abstract}
This study was designed to follow up whether or not the creativity of adolescents showed significant changes in the 9th and $12 \mathrm{~h}$ grades and is a longitudinal study. Correlational screening model, which is one of the descriptive methods, was used in this study. The sample group consisted of a total of 145 ( 76 girls, 69 boys) adolescents who were attending Yozgat High School in the city center of Yozgat, Turkey in the 2014-2015 school year and were selected from the 9th grade by using random sampling method. When the sample group came to the 12th grade, the number of the adolescents decreased to 136 (72 girls, 64 boys). The analyses were made based on the data collected from 136 adolescents who were available in the 12th grade. General Information Form and Torrance Test of Creative Thinking (Figural Form A) were used as the data collection tool. In the data analysis, frequency from descriptive statistics, Paired-Samples T-Test for repeated measures and t-test for unrelated measures were applied. As a result of the study, it was found that the scores of the fluency scores and resistance to premature closure scores of the adolescents who participated in the study in the 9th grade significantly differed from their fluency scores and resistance to premature closure scores in the 12th grade, and this differentiation was in favor of the fluency and resistance to premature closure scores of the 9th grade. Their elaboration scores in the 9th grade differed statistically significantly from their elaboration scores in the 12th grade and this differentiation was in favor of their elaboration points in the 12th grade $(p<.05)$. The scores of abstractness of the titles in the 9th grade were in favor of the scores of female adolescents and also the fluency scores of the participants in the 12th grade were in favor of male adolescents and this differed statistically based on gender $(\mathrm{p}<.05)$.
\end{abstract}

Keywords: adolescent, creativity, creativity and class level, creativity and gender, longitudinal study.

\section{Introduction}

When the researches about creativity are examined, it is considered that the concept of creativity is as old as the history of humanity, it has been adopted as a phenomenon related to the field of fine arts only for the last five hundred years, and it has been evaluated within a mystical framework, mostly trying to be explained by de genius or divine and extraordinary

${ }^{\star}$ Corresponding author. E-mail: gunes.sali@bozok.edu.tr 
powers, over time; however, it is seen all areas of life. Creativity, which is defined and explained by thinkers and researchers in different ways (San, 2004b), is both a product, a mental process, and a psychological dimension. Therefore, it is very difficult to define and express creativity (Ataman, 1993), and to adopt or accept a single meaning. The creativity addressed by many scientists and thinkers is a broad concept which has different meanings in every discipline and has a lot of meanings in this respect (Can Yaşar, 2009).

According to Howard Gardner's (1993) theory of multiple intelligences, he defines intelligence as "the ability to solve problems or create new products that are valuable to one or more cultural formations" and this definition is rather the definition of creativity (Hurlock, 1978, cited by Ataman, 1993, p. 115). Gardner (1993) also stated in his views on multiple intelligence that creativity has a characteristic that can be developed, expressed and applied in different contexts through different kinds of communication. Gardner also states that creativity includes the solution of a well-defined problem, the design of a theory covering the whole society, and the realization of a ritualized work. On the other hand, it is emphasized that creativity is associated with daily life and includes both individual and group work (Prentice, Matthews, \& Taylor, 2003). Mihaly Csikszentmihalyi also states that creativity is a behavior developing as a result of interaction between individuals' thoughts and sociocultural context (1996).

Ellis Paul Torrance (1995) defined creativity as the process of creating ideas or assumptions, testing assumptions and explaining results. This idea states that creativity covers the production of new or original something and includes thinking "beyond borders". Exploration, review, imagination, invention and curiosity are included in this. Torrance (1995) defined creativity as the process of creating ideas or assumptions, testing assumptions, and explaining results. Accordingly, creativity involves producing something new or original. It involves thinking beyond borders. This includes exploration, investigation, imagination, invention and curiosity. Torrance also points out that creativity is evident in scientific theories, inventions, improved products, novels, poems, designs, paintings, music, and dance. Florence Beetlestone (1998) emphasizes the presence of six elements to define creativity as description (expressing ideas and emotions); productivity (imagination, creation, formation, authorship, performance); authenticity (taking risks and being out of the ordinary); creative thinking (CT) and problem solving (PS) (different and less obvious solutions); and the universe and its creation-nature (emotional interaction between the individual and the environment). Likewise, Beetlestone (1998) has argued that each person has more or less creativity and all children can rearrange ideas and create meaning in original ways. L. Roberts (2003) states that creativity is a feature found in everyone and the individual has the ability to find new things by using his imagination while doing an activity. Joan P. Isenberg and Mary Renck Jalongo (1993) define creativity as a process of thinking and reacting that includes combining previous experiences, reacting to stimulus (objects, symbols, thoughts, people, situations) and creating at least one special association.

The researchers, who assessed the creativity process as a process of "doing and creating" by using previously acquired knowledge and adding new experiences to the old experiences and focused mostly on creativity in the field of art, tried to define creativity from a different dimension. According to Mary Lowden (1989), creativity is not unusual for arts, exists in the 
creation of human being, is related to human activities, and deals with science as much as art. Beetlestone (1998) states that creativity and art are closely related and emphasizes that children should adopt the process and product to be motivated. Similarly, Torrance (1995) states that creativity covers finding something new for the child and contributing to the group of the child, and highlights the importance of discovery and invention. Anna Craft (2003) describes creativity as a lifelong talent not related to art and defines creativity as the capacity to express oneself and to use intelligence and imagination. According to Todd I. Lubart (1994), creativity is the ability to produce a new (different) and appropriate work. Robert Sternberg and Lubart (1995) state that "innovation" and "conformity" elements are required for the creative product and believe that creativity is present somehow in every human being just like intelligence and each individual's level of creativity can be improved in varying degrees.

When the creativity definitions are examined, it is seen that "new" or "innovation" characteristics, namely, the concepts of originality or invention is used as common and is composed of the ability to produce useful ideas and/or products (Sternberg, 2005). In most of the definitions, process-product-experience elements are described as common points (Can Yaşar, 2009).

Although CT and creativity do not mean the same, they are still used interchangeably. CT refers to mainly mental activities; on the other hand, creativity refers to both mental and performance-based activities. Creativity also includes CT as a more general concept (Doğan, 2005). J. P. Guilford (1950) made the distinction between convergent thinking (COT) (analytical) and divergent thinking (DT) (critical) and gave the broadest and clearest explanation to CT. COT is to achieve the conclusion by make ordinary reasoning. This result is a known result almost everyone can reach within the framework of simple logic principles. It is logical and can lead to a single response or a small number of practicable solutions. COT focuses on determining correct answers. DT, on the other hand, is the finding of many possible solutions to questions that have many objective correct answers or no true answer. DT is effective in answering most of the complex questions of life. These questions force individuals to consider various possibilities, options and outcomes. It invokes numerous possible responses by evoking individual perspectives (Guilford, 1950, cited by Gartenhaus, 2000).

While COT is expected, determined and directed to the usual responses, DT is a freely and spontaneously emerging thought in which nothing has been determined in advance (San, 1985, 2004a). COT, however, is effective in case of a problem that can be solved by using the predetermined and known methods. Such thinking may also be useful, but the basis point of actual CT is DT. While COT directs to the expected, specific or compromising responses, DT reveals the quality of CT processes. Creativity enables to develop new ideas and produce new options (NOs). There is a need for DT in the production of NOs. It can be explained by CT, generalization of the thoughts intertwined with creativity, thought processes, experiences and decisions. DT involves the evaluation of all these (San, 1977, 2004a, 2004b; Üstündağ, 2014). Since DT is more flexible than COT and open to richer thoughts, it is a type of thinking that has tendency to creativity. Therefore, creativity originates from DT (Cropley, 1997; Aral, 2000; Gartenhaus, 2000).

Beetlestone (1998) suggests that all young children start as divergent thinkers and become gradually more convergent thinkers as they grow and socialized into different response 
models. Craft (2003) states that CT involves COT, whereas, Deborah W. Tegano, James D. Moran III and Janet K. Sawyers (1991) states that DT and COT are complementary for each other and important for creativity.

Although there are factors supporting the development of creativity (DC) in early childhood period, both the motivation and the creation capacity are firstly seen during adolescence period. Creative capacity (CC) starts with structuring developmental tasks during adolescence. The results of an experimental study on creativity showed that the development of CC took place primarily during adolescence period (Rothenberg, 1990, 2016). The fact that adolescence coincides with formal operational period in terms of cognitive development may support this finding.

Adolescence is a stage of development characterized by flexible adaptation to the rapidly changing social environment, which leaves its mark from dependence to autonomy and from individuality to the changes (Crone \& Dahl, 2012). It constitutes a very important stage for the development of cognitive abilities assumed to be associated with creative cognition such as working memory and cognitive control (Diamond, Kirkham, \& Amso, 2002; Bunge \& Wright, 2007; Huizinga \& Molen, 2007; Crone \& Dahl, 2012). Working memory (Klingberg, 2010; Jolles \& Crone, 2012), executive control (Karbach \& Kray, 2009; Zinke, Einert, Pfennig, \& Kliegel, 2012), training on other high cognitive skills such as relational reasoning (Dumontheil, Houlton, Christoff, \& Blakemore, 2010), and the ability to solve algebraic equations emphasize the flexibility of the adolescent brain (Qin et al., 2004). Since adolescence coincides with formal operational period in terms of cognitive development, this period may be suitable for developing of creative cognition-related abilities.

The ability to produce creative ideas (CIs) varies from childhood to adulthood and seems changing. The alternative uses task (AUT)/production is a widely used CI index of adults in general. An experimental research has been conducted in order to see whether or not performance can be increased by applying AUT in relation to the development of CT skills. The effectiveness of CT education on adolescents $(13-16$ years, N. = 71) and adults (23-30 years, N. = 61) was investigated. The participants followed one of three types of training, each of which included eight 20 -minute practice sessions within 2 weeks:

(1) alternative use generation (experimental condition: $\mathrm{CI}$ );

(2) formation of object characteristic generation (control condition: general thinking);

(3) change of rule (check condition: change rule).

Fluency, flexibility, and progression on the originality of CT were compared between age groups and educational conditions. The participants developed in CT and cognitive flexibility but did not make progress in overall thinking. The participants in each of three training conditions progressed in fluency and originality in AUT. Concerning originality, adolescents were more advanced than adults after the training (Stevenson, Kleibeuker, Dreu, \& Crone, 2014; Kleibeuker, Dreu, \& Crone, 2016). These results were seen in relation to the developmental differences in brain plasticity with (a) different basic processes aimed in three conditions and (b) increased sensitivity to education in adolescents. In summary, the results indicated that CT can be improved and the adolescence period supports the hypothesis that there is a developmental stage of flexibility optimized for learning and research behavior (Stevenson et al., 2014; Kleibeuker et al., 2016). It is stated that after puberty period, which is 
the beginning of adolescence, adolescents may be more advantageous for discovery ideation (Johnson \& Wilbrecht, 2011).

In a study evaluating the development of creative cognition during adolescence, participants $(\mathrm{N}=98)$ divided into four age groups (12-13 years, 15-16 years, 18-19 years and 25-30 years) were exposed to a series of tasks measuring creative insight $(\mathrm{N}=98)$ (visual, oral and different thoughts (verbal, visual spatial). Two older age groups (18-19 years and 25-30 years) performed better for insight tasks than two younger age groups (12-13 years, 15-16 years). Participants between the ages of 25-30 performed better than the two youngest age groups (12-13 years, 15-16 years) according to the authenticity of verbal different thinking (DIT). No difference in age group was observed in terms of verbal DT fluency and flexibility. In the visual spatial field, only 15-16 year olds performed better than 12-13 year olds. A model with the highest performance between the ages of 15-16 showed the best fit. It is stated that the results of different creativity processes are related to cognitive and related neurobiological models. It is concluded that middle adolescence creates creative potentials (CRPs) in the visual spatial domain (Kleibeuker, Dreu, \& Crone, 2013). When these results are taken into consideration, it can be said that middle adolescence is as critical as the preschool period in developing creativity.

Researches have shown that school programs (SPs) do not provide a suitable place and do not create a proper environment for the development of CRP. When the literature is examined, it is seen that the research studies in the field of creativity have gradually increased. Comprehensive studies have been conducted at both institutional and individual level. It has been observed that SPs do not provide a suitable place and do not create a proper environment for the development of CRP. This may be due to the fact that contributions of creative talent (CRT) to national development are not recognized, teacher understand creative process (CP) insufficiently or have difficulty in identifying creative children or the factors accelerating the DC are not known. All CPs need to be developed and recognized to prevent cultural stagnation and promote cultural viability and renewal. Creative adolescents are a national resource and should be identified at the school stage and allowed to follow the field of activity in which they are able to show their talents (Hanarick \& Neeraj, 2018). For this purpose, updates can be made to support creativity in SPs by taking into consideration the needs of time, space and children's needs.

In the existing information society, knowledge bases are rapidly changing and growing, and continuous innovations are critical. Therefore, CT is considered as “21st century's superior skill". Flexibility and unconventional thinking as well as the ability to produce and test multiple solutions for DIT and problems are now as valuable and important as ever (Kleibeuker et al., 2016). Creativity is the potential of human life that affects almost all living areas and most of the changes and development in society are the result of CT ability. No nation cannot compensate the waste of CRTs in today's age. CRT can change the course of history by reshaping the world. In order to survive in international competition, it is important to encourage and support the identification and development of creative persons (Hanarick \& Neeraj, 2018). Nations realizing this can take precedence over other nations by taking steps to develop and support creativity in all levels and areas of education.

In a rapidly globalizing world, a few talents being more important than "creativity", can be listed for mankind's progress. Modern life makes it essential and mandatory for individuals 
to use their "CT skills" that will enable them to bring qualified solutions for the complex social, individual and professional problems of the society. However, formal education does not support "DT", which is the most important dimension of creativity, as desired (Rudowicz, Kitto, \& Lok, 1992; Ataman, 1993). It is more focused on COT.

It can be said that in the education process, a society or culture environment that brings the unknown to the agenda instead of giving ready information that is constantly changing and losing its validity in a short time, is encouraging creativity or at least is more favorable to grow creative individuals (Güvenç, 1993). In contemporary countries, one of the main criticisms of compulsory education and education system is related to the prevention of the DC. In order for the education system to give students the opportunity to develop their potential and play an active role in the development of the country, the content and methods of teaching should be re-arranged in such a way as to acquire skills such as critical thinking, scientific thinking, relational thinking, reasoning and CT (Doğan, 2005). The CT ability makes an important to the acquisition of knowledge and various educational skills (Getzels \& Jackson, 1962). When considering the importance of creativity in every aspect of life, including education, there is a need to research the field more scientifically (Hanarick \& Neeraj, 2018). This could be one of the best investments in the future.

In the literature review, it is seen that studies conducted in the nation mainly focused on the relationship between creativity and demographic variables (Çetingöz, 2002) and the effect of education programs (EPs) on CT (Atkıncı, 2001; Yaman \& Yalçın, 2005; Sonmaz, 2002). It is seen that CT skills have been studied in every age period from pre-school to adulthood (Salı \& Köksal Akyol, 2015; Köksal Akyol \& Sal1, 2016; Yüksel, 2016; Kayar, 2016; Runco, Acar, \& Cayirdag, 2017).

When the studies conducted in abroad on creativity are examined, it is seen that there are findings in a wide range such as demographic variables (Matud, Rodríguez, \& Grande, 2007), social-emotional characteristics (Reza Tamannaeifar \& Motaghedifard, 2014), and brain functionality (Kleibeuker et al., 2017). Similar to the studies conducted in Turkey, there are studies conducted in abroad on CT EPs (McGregor, 2001; Y. C. Yeh, Y. H. Yeh, Li, \& Pen, 2006) and the relationship between CT and teaching programs (Laius \& Rannikmae, 2005). However, there have been very few studies (Sal1, 2015; Im, Hokanson, \& Johnson, 2015) where creativity is studied longitudinally both in Turkey and abroad.

For these reasons, longitudinal examination of DC in adolescents is considered important. It is hoped that the results of this study would help both parents and teachers to identify and support the creative senses of adolescent students. Based on the importance of DC in adolescence, the aim of the study was to investigate whether the creativity of adolescents (CAs) showed significant changes in the 9th and 12th grades. In order to achieve this purpose, variables related to creativity levels were followed once in each of two academic year of the sample group (SG). Answers of the following questions were sought in the study:

1. Do the creativity subscale scores and total scores of the adolescents participating in the study in the 9th and 12th grades differ?

2. Do the creativity subscale scores and total scores of the adolescents participating in the study in the 9th and 12th grades differ based on gender? 


\section{Method}

\subsection{Research model}

In this study, which was designed to examine the CAs in the 9th and 12th grades, correlational screening model, which is one of the descriptive methods, was used. This study was also a longitudinal study (LS). Correlational screening method is the research models aiming to determine the presence and/or degree of covariance between two and more variables (Karasar, 2009). In the LS, the variable, whose temporal development or variance is requested to be determined, is continuously or periodically observed on the same element or units by being taken from a certain starting point. It is an appropriate approach especially when it is desired to make extensive observations to its depth and width (Karasar, 2009, p. 80).

\subsection{Sample group}

The SG consisted of a total of 145 (76 girls, 69 boys) adolescents who were attending Yozgat High School located in the city center of Yozgat and were determined from the 9th grade in the 2014-2015 school year by using random sampling. When the SG came to the 12 th grade, the number of the adolescents in the SG decreased to 136 (72 girls, 64 boys). Table 1 shows the gender-based distribution of the sample by years.

Table 1. Gender-based distribution of the sample by years (source: created by author)

\begin{tabular}{|l|c|c|}
\hline \multicolumn{1}{|c|}{ Application time } & Gender & $\mathrm{N}$ \\
\hline \multirow{3}{*}{ In the 9th grade } & Girl & 76 \\
\cline { 2 - 3 } & Boy & 69 \\
\cline { 2 - 3 } & Total & 145 \\
\hline \multirow{3}{*}{ In the 12th grade } & Girl & 72 \\
\cline { 2 - 3 } & Boy & 64 \\
\cline { 2 - 3 } & Total & 136 \\
\hline
\end{tabular}

\subsection{Data collection tools}

General Information Form (GIF) and Torrance Test of Creative Thinking (TTCT) (Figural Form A (FFA)) were used as the data collection tool in the study.

\subsubsection{General information form}

The form developed by the researcher was used to determine the demographic characteristics of the children participating in the study.

\subsubsection{Torrance Test of creative thinking (Figural Form A)}

The test developed by Torrance in 1966 consists of verbal and figural sections. Verbal and figural tests (VFTs) have A and B forms. The subtests in VFTs of the TTCT are aimed at revealing the high number of ideas that are required for PS, are in a very different area, 
are quite rare, and requires creative ability. Creativity in figural test is assessed under the subscales of fluency, originality, abstractness of titles (ATs), elaboration, and resistance to premature closure (RPMC). There are three sub-tests (picture construction (PC), picture completion (PIC) and parallel lines (PLs) in TTCT (FFA) of the test.

$P C$ : It is requested to complete the geometric figure for creating a new figure, to create a story about this new figure or to give a name.

PIC: The child is asked to create a new figure by using 10 unfinished lines and name it.

PLs: It is aimed to test different responses that can be given to the same type of stimulus. With thirty PLs, new figures are requested to be created and named.

Circles: It is aimed to test different responses that can be given to the same type of stimulus. It is asked to create and name new figures with 42 circles.

Fluency is defined as developing many alternatives for a problem (R. P. Rein \& R. Rein, 2000) and producing many ideas, thoughts and associations. Originality is defined as the ability to produce unordinary, different, and unique solutions against a problem (R. P. Rein \& R. Rein, 2000), creating unique, rare, and rational thoughts or bringing new specific solutions or producing new, unordinary, and rare ideas. Elaboration is used as the ability to develop or expand the idea, story or drawing of some else (R. P. Rein \& R. Rein, 2000), enhancing a simple stimulus in a detailed and elaborative manner, entering into details, and adding answers (Torrance \& Goff, 1989; Öncü, 2003; Erlendsson, 1999). The ATs is related to realization of the processes, synthesis of processes, and organization. At the highest level, it is important to be able to examine the essence of the information in question and to know what is important. This type of title allows the person, who is looking at the picture, to see the picture more deeply and richly. $R P M C$ is used as delaying closure enough to make the mental jump that makes the original ideas possible instead of tending to leap forward to premature results without considering the potential information and keeping the mind open (Aslan, 2001).

Two measurements as norm-based measurements (NBMs) and criteria-based measurements (CBMs) were taken into consideration during the evaluation of the test. NBMs are five; fluency, originality, ATs, elaboration, and resistance to premature closure. Fluency score is obtained as a result of assessing PIC, PLs tests. Originality score is obtained as a result of assessing PC, PIC, and PLs tests. The score of ATs resistance is obtained as a result of assessing PC and PIC tests. The elaboration score is obtained as a result of assessing PC, PIC, and PLs tests. The score of RPMC is obtained as a result of assessing PIC test. On the other hand, CBMs are examined under thirteen dimensions. These dimensions are emotional expressions (EEs), storytelling, movement or activity (MA), the clarification of the titles (CLTs), the completion of unfinished figures (CUFFs), the synthesis of unfinished lines (SUFLs), unusual visualization (UNUV), internal visualization (IV), expanding or passing borders (EPBs), humor, richness of imagination (RI), imagination diversity (ID), and fantasy. For each of the three tests (PC, PIC, PLs, or circles) scores are evaluated in the dimensions of EEs, storytelling, MA, the CLTs, the CUFFs, the SULFs, UNUV, IV, EPBs, humor, RI, ID, and fantasy. As a result of the evaluation of TTCT (FFA); a score of the Creative Forces List (CFL) is obtained by considering the criteria in the CFL except for scores of the subscales of fluency, originality, ATs, elaboration and resistance to premature closure. Total creativity (TC) score is calculated by adding the mean scores obtained by the child from five subscales and total scores of CBMs in the CFL (Aslan, 2001). 
The verbal and figural parts of the TTCT developed by Torrance in 1966 were adapted into Turkish by Esra Aslan (2001) and the translation of the test, the Turkish adaptation of the test items, and the validity and reliability of its Turkish translation were investigated. The correlation between English and Turkish test applications was highly significant for overall figural creativity $(r=0.59)$. In the internal consistency analyses made using Spearman-Brown prediction formula, Guttmann's and Cronbach's alpha techniques, correlation coefficients were between $r=0.38$ and $r=0.89$. The lowest and highest Cronbach's alpha values of the pre-school group were found to be .50 and .71, respectively. In the scope of validity studies, internal validity and external validity studies were conducted. Under the title of criterion validity, the adjective list, Wechsler Adult Intelligence Scale and the Wonderlic Test (Cognitive Ability Test) were used and as a result of the analyses, the test was found to be reliable for all age groups and score types (Aslan, 2001). Within the scope of this study, the reliability study of the test was carried out again. In the TTCT (FFA), the reliability coefficient (RC) (alpha) was determined as 0.727 for fluency subscale, 0.725 for originality subscale, 0.826 for ATs subscale, 0.826 for elaboration subscale, and 0.820 for RPMC subscale. The $\mathrm{RC}$ (alpha) of the overall test was 0.677 . Within the scope of this study, the reliability study of the TTCT (FFA) was carried out again.

Table 2 shows the RCs of both applications of TTCT (FFA) and its subscales. Total RCs of the test were determined to be 0.773 and alpha (0.789), respectively. According to the calculated alpha value, it can be asserted that TTCT (FFA) is a reliable data collection tool.

\subsection{Data collection and analysis}

Necessary permission for the study was obtained from the Provincial Directorate of National Education under Yozgat Governorship. The data collection process was performed by applying the test twice in the same SG. The first stage of data collection was carried out in six 9th-grade branches of a high school affiliated with the Ministry of National Education in the city center of Yozgat in May in the second semester of the 2014-2015 school year. In the study, before the application, the researcher informed the school administrators and

Table 2. Torrance Test of Creative Thinking (Figural Form A's) reliability test results (source: created by author)

\begin{tabular}{|l|c|c|}
\hline \multicolumn{1}{|c|}{ SUBSCALES OF THE TEST } & $\begin{array}{c}\text { Alpha value of the application } \\
\text { in the 9th grade }\end{array}$ & $\begin{array}{c}\text { Alpha value of the application } \\
\text { in the 12th grade }\end{array}$ \\
\hline Fluency & .803 & .781 \\
\hline Originality & .791 & .772 \\
\hline Abstractness of titles & .813 & .830 \\
\hline Elaboration & .808 & .806 \\
\hline Resistance to premature closure & .802 & .806 \\
\hline Total creativity & .773 & .789 \\
\hline
\end{tabular}


teachers about the general purpose of the study, and the principles of confidentiality and volunteerism. The applications carried out on a voluntary basis were carried out in a wide and quiet classroom environment in order to prevent the participants from being affected from other participants. During the application, the participants were given ten minutes for each of the sub-tests (PC, PIC, PLs) to complete the tests. The test materials were then collected. The implementation of the test lasted for approximately fifty minutes with explanations for each session. Upon the request of the participants, the GIF was given to each participant after the about ten-minute break. After the answering process was completed, these forms were collected and thus the first application was completed. When the SG came to the 12th-grade (2017-2018), the creativity test was applied again in May in the second semester. The sample number including 145 children (76 girls, 69 boys) in the 9th grade was 147 ( 72 girls, 75 boys) decreased to 136 children in the 12 th grade ( 72 girls, 64 boys). The analyses were made based on the data collected from 136 children who were reached in the 12th grade. Therefore, in this study, the analyses were made by using the data obtained from the data collection tools applied to 136 children, which can be reached for both applications. In the analysis of the data, normality tests were performed first. Table 3 and Figure 1 show Shapiro-Wilk test results and histogram, respectively. In the data analysis, frequency from descriptive statistics, Paired-Samples T-Test (PSTT) for repeated measures and t-test for unrelated measures were applied (Büyüköztürk, 2007).

Table 3. Normality analysis of Torrance Test of creative thinking (Figural Form A) and subscale scores (source: created by author)

\begin{tabular}{|c|c|c|c|c|c|}
\hline \multicolumn{6}{|c|}{ NORMALITY TESTS } \\
\hline \multirow{14}{*}{$\begin{array}{l}\text { Torrance Creative } \\
\text { Thinking Scale } \\
\text { Shape Form A }\end{array}$} & & & & apiro- & \\
\hline & & & Statistic & df & $\mathrm{p}$ \\
\hline & \multirow{6}{*}{$\begin{array}{l}\text { Application in } \\
\text { 9th grade }\end{array}$} & Fluency & .976 & 136 & .016 \\
\hline & & Originality & .985 & 136 & .154 \\
\hline & & Abstractness of titles & .916 & 136 & .000 \\
\hline & & Elaboration & .970 & 136 & .004 \\
\hline & & Resistance to premature closure & .939 & 136 & .000 \\
\hline & & Total creativity & .988 & 136 & .282 \\
\hline & \multirow{6}{*}{$\begin{array}{l}\text { Application in } \\
\text { the 12th grade }\end{array}$} & Fluency & .957 & 136 & .000 \\
\hline & & Originality & .932 & 136 & .000 \\
\hline & & Abstractness of titles & .906 & 136 & .000 \\
\hline & & Elaboration & .961 & 136 & .001 \\
\hline & & Resistance to premature closure & .977 & 136 & .021 \\
\hline & & Total creativity & .947 & 136 & .000 \\
\hline
\end{tabular}



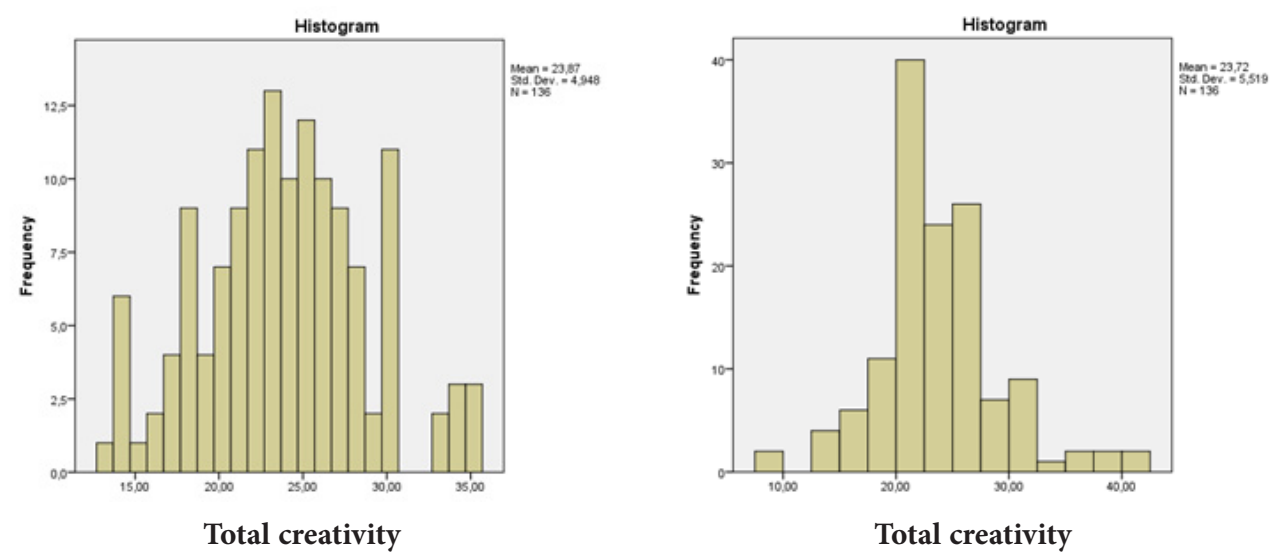

Figure 1. Histograms of the total scores of Torrance Test of Creative Thinking (Figural Form A) obtained from the 9th- and 12th-grade application results (source: created by author)

\section{Results}

\subsection{Results concerning whether or not the creativity subscale scores and total scores of the participants differed in the 9th grade and 12th grade}

Table 4 shows the results concerning the research question "Do the creativity subscale scores and total scores of the adolescents participating in the study in the 9th and 12th grades differ?", which was the primary objective of the study.

Table 4. Paired-Samples T-Test results of the creativity scores of the adolescents in the 9th and 12th grades (source: created by author)

\begin{tabular}{|c|c|c|c|c|c|c|c|c|}
\hline Subscale & Application time & $\mathrm{N}$ & $\bar{X}$ & Ss. & sd & $\mathrm{t}$ & $\mathrm{p}$ & $\begin{array}{l}\text { Significant } \\
\text { difference }\end{array}$ \\
\hline \multirow[t]{2}{*}{ Fluency } & In the 9th grade & 136 & 25.95 & 8.10 & 135 & 2.09 & $0.045^{\star}$ & $1-2$ \\
\hline & In the 12 th grade & 136 & 24.68 & 6.95 & & & & \\
\hline \multirow[t]{2}{*}{ Originality } & In the 9th grade & 136 & 21.01 & 7.42 & 135 & -0.091 & 0.927 & \\
\hline & In the 12 th grade & 136 & 21.07 & 6.40 & & & & \\
\hline \multirow{2}{*}{$\begin{array}{l}\text { Abstractness } \\
\text { of titles }\end{array}$} & In the 9th grade & 136 & 5.01 & 3.71 & 135 & -1.803 & 0.074 & \\
\hline & In the 12 th grade & 136 & 5.74 & 5.05 & & & & \\
\hline \multirow[t]{2}{*}{ Elaboration } & In the 9th grade & 136 & 11.05 & 2.16 & 135 & -7.426 & $0.000^{*}$ & $2-1$ \\
\hline & In the 12 th grade & 136 & 12.79 & 3.08 & & & & \\
\hline \multirow{2}{*}{$\begin{array}{l}\text { Resistance } \\
\text { to premature } \\
\text { closure }\end{array}$} & In the 9th grade & 136 & 14.70 & 3.23 & 135 & 6.191 & $0.000^{*}$ & $1-2$ \\
\hline & In the 12 th grade & 136 & 12.50 & 3.85 & & & & \\
\hline \multirow{2}{*}{$\begin{array}{l}\text { Total } \\
\text { creativity }\end{array}$} & In the 9th grade & 136 & 23.87 & 4.95 & 135 & 0.297 & 0.767 & \\
\hline & In the 12 th grade & 136 & 23.72 & 5.52 & & & & \\
\hline
\end{tabular}

${ }^{*} p<.05$. 
It was determined that the fluency scores and the RPMC scores $\left.\left(t{ }_{135}\right)=6.191, \mathrm{p}<.05\right)$ of the adolescents in the 9th grade $\left.\left(\mathrm{t}{ }_{(135}\right)=2.019, \mathrm{p}<.05\right)$ significantly differed from their scores in the 12th grade and this differentiation was in favor of fluency and premature closure scores in the 9 th grade.

The elaboration scores $\left(\mathrm{t}\left({ }_{135}\right)=-7.426, \mathrm{p}<.05\right)$ in the 9 th grade differed from the elaboration scores in the 12th grade in a statistically significant manner and this differentiation was in favor of the elaboration scores in the 12th grade. No significant differentiation was observed in the scores of the originality $\left(\mathrm{t}\left({ }_{135}\right)=-0.091, \mathrm{p}>.05\right)$ and the ATs $\left(\mathrm{t}\left({ }_{135}\right)=\right.$ $-1.803, \mathrm{p}>.05)$ subscales and the TC score $\left.\left(\mathrm{t}{ }_{(135}\right)=0.297, \mathrm{p}>.05\right)$. These results indicated that the fluency and RPMC scores of the adolescents in the 9th grade decreased in the 12th grade; their elaboration scores in the 9th grade increased in the 12th grade; their scores of originality and the ATs subscales and their TC scores did not change in both applications.

\subsection{Results concerning whether or not the creativity subscale scores and total scores of the participants in the 9th grade and 12th grade differed based on gender}

Tables 5 and 6 show the results concerning the research question "Do the creativity subscale scores and total scores of the adolescents participating in the study in the 9th and 12th grades differ based on gender?", which was the secondary objective of the study.

When Table 5 was examined, it was observed that scores obtained by the adolescents from the ATs subscale $\left(\mathrm{t}\left(_{134}\right)=3.231, \mathrm{p}<.05\right)$ in the 9th grade differed based on gender and this differentiation was in favor of scores of the female adolescents (FAs). When the Eta-squared $\left(\eta^{2}\right)$ value was examined, it was determined that the effect of gender on the fluency subscale score was $07 \%$. No significant differentiation was observed in scores of flu-

Table 5. T-test results of the creativity scores of the adolescents in the 9th grade based on gender (source: created by author)

\begin{tabular}{|c|c|c|c|c|c|c|c|c|c|}
\hline Subscale & $\begin{array}{l}\text { Application } \\
\text { time }\end{array}$ & $\mathrm{N}$ & $\bar{X}$ & Ss. & sd & $\mathrm{T}$ & $\mathrm{p}$ & $\eta^{2}$ & $\begin{array}{l}\text { Signifi- } \\
\text { cant dif- } \\
\text { ference }\end{array}$ \\
\hline \multirow[t]{2}{*}{ Fluency } & Girl & 72 & 24.94 & 8.27 & 134 & -1.542 & 0.126 & 0.017 & \\
\hline & Boy & 64 & 27.08 & 7.81 & 134 & & & & \\
\hline \multirow[t]{2}{*}{ Originality } & Girl & 72 & 20.83 & 7.64 & 134 & -0.301 & 0.764 & 0.001 & \\
\hline & Boy & 64 & 21.22 & 7.22 & 134 & & & & \\
\hline \multirow{2}{*}{$\begin{array}{l}\text { Abstractness of } \\
\text { titles }\end{array}$} & Girl & 72 & 5.94 & 3.85 & 134 & 3.231 & $0.002^{*}$ & 0.072 & $1-2$ \\
\hline & Boy & 64 & 3.95 & 3.27 & 134 & & & & \\
\hline \multirow[t]{2}{*}{ Elaboration } & Girl & 72 & 11.28 & 1.79 & 134 & 1.298 & 0.196 & 0.012 & \\
\hline & Boy & 64 & 10.80 & 2.51 & 134 & & & & \\
\hline \multirow{2}{*}{$\begin{array}{l}\text { Resistance } \\
\text { to premature } \\
\text { closure }\end{array}$} & Girl & 72 & 14.38 & 3.61 & 134 & -1.241 & 0.217 & 0.011 & \\
\hline & Boy & 64 & 15.06 & 2.72 & 134 & & & & \\
\hline \multirow[t]{2}{*}{ Total creativity } & Girl & 72 & 24.42 & 4.88 & 134 & 1.384 & 0.169 & 0.014 & \\
\hline & Boy & 64 & 23.25 & 4.99 & 134 & & & & \\
\hline
\end{tabular}

${ }^{*} p<.05$. 
ency $\left(\mathrm{t}_{(134)}=-1.542, \mathrm{p}>.05\right)$, originality $\left(\mathrm{t}_{(134)}=-0.301, \mathrm{p}>.05\right)$, elaboration $\left(\mathrm{t}_{(134)}=1.298\right.$, $\mathrm{p}>.05), \mathrm{RPMC}\left(\mathrm{t}_{(135)}=-1.241, \mathrm{p}>.05\right)$ subscales and TC score $\left(\mathrm{t}_{(134)}=1.384, \mathrm{p}>.05\right)$. Even though it was not a significant difference, mean scores of the male adolescents (MAs) were higher in fluency $\left(\bar{X}_{\mathrm{E}}=27.08, \bar{X}_{\mathrm{K}}=24.94\right)$ originality $\left(\bar{X}_{\mathrm{E}}=21.22, \bar{X}_{\mathrm{K}}=20.83\right) \mathrm{RPMC}$ ( $\left.\bar{X}_{\mathrm{E}}=15.06, \bar{X}_{\mathrm{K}}=14.38\right)$ subscales; on the other hand, mean scores of the FAs were higher in elaboration subscale $\left(\bar{X}_{\mathrm{K}}=11.28, \bar{X}_{\mathrm{E}}=10.80\right)$ and TC $\left(\bar{X}_{\mathrm{K}}=24.42, \bar{X}_{\mathrm{E}}=23.25\right)$.

It was determined that the adolescents' fluency scores $\left(\mathrm{t}\left({ }_{134}\right)=-2.433, \mathrm{p}<.05\right)$ in the 12 th grade differed based on gender and this differentiation was in favor of the scores of MAs. When the Eta-squared $\left(\eta^{2}\right)$ value was examined, it was determined that the effect of gender on the fluency subscale score was $04 \%$. No significant differentiation was observed in scores of originality $\left(\mathrm{t}\left({ }_{134}\right)=-1.876, \mathrm{p}>.05\right)$, ATs $\left(\mathrm{t}\left({ }_{134}\right)=1.625, \mathrm{p}>.05\right)$, elaboration $\left(\mathrm{t}\left({ }_{134}\right)=0.857, \mathrm{p}>.05\right)$, RPMC $\left(\mathrm{t}\left({ }_{134}\right)=-0,400, \mathrm{p}>.05\right)$ subscales and TC score $\left(\mathrm{t}\left({ }_{134}\right)=0.373, \mathrm{p}>.05\right)$. Although there was no significant difference, the mean scores of MAs were higher in the originality subscale $\left(\bar{X}_{\mathrm{E}}=22,16, \bar{X}_{\mathrm{K}}=20,11\right)$; whereas, the mean scores of the FAs were higher in the subscales of $\stackrel{\mathrm{E}}{\mathrm{A}} \mathrm{Ts}(\mathrm{K}=6.40, \mathrm{E}=5.00)$ and elaboration $\left(\bar{X}_{\mathrm{K}}=13.00, \bar{X}_{\mathrm{E}}=12.55\right)$.

When the results in Tables 5 and Table 6 were examined together, it was indicated that the scores obtained by the MAs from the subscales of fluency, originality and RPMC in the 9th grade were higher than the scores of the FAs; additionally their fluency and originality scores in the 12th grade were higher than girls. On the other hand, the ATs, elaboration, and TC scores of the FAs in the 9th grade were higher than the scores of the MAs and their scores of ATs and elaboration in the 12th grade were higher than the scores of the MAs. As a result, it can be asserted that while the MAs maintained their high fluency and originality scores, the FAs maintained their high ATs and elaboration scores in both applications.

Table 6. T-test results of the creativity scores of the adolescents in the 12th grade based on gender (source: created by author)

\begin{tabular}{|l|c|c|c|c|c|c|c|c|c|}
\hline \multicolumn{1}{|c|}{ Subscale } & $\begin{array}{c}\text { Application } \\
\text { time }\end{array}$ & $\mathrm{N}$ & $\bar{X}$ & Ss. & $\mathrm{sd}$ & $\mathrm{T}$ & $\mathrm{p}$ & $\eta^{2}$ & $\begin{array}{c}\text { Significant } \\
\text { difference }\end{array}$ \\
\hline Fluency & Girl & 72 & 23.33 & 5.51 & 134 & -2.433 & $0.016^{*}$ & 0.042 & $1-2$ \\
\cline { 2 - 12 } & Boy & 64 & 26.19 & 8.06 & 134 & & & & \\
\hline \multirow{2}{*}{ Originality } & Girl & 72 & 20.11 & 5.80 & 134 & -1.876 & 0.063 & 0.026 & \\
\cline { 2 - 12 } & Boy & 64 & 22.16 & 6.91 & 134 & & & & \\
\hline $\begin{array}{l}\text { Abstractness of } \\
\text { titles }\end{array}$ & Girl & 72 & 6.40 & 4.84 & 134 & 1.625 & 0.106 & 0.019 & \\
\cline { 2 - 12 } & Boy & 64 & 5.00 & 5.22 & 134 & & & & \\
\hline \multirow{2}{*}{ Elaboration } & Girl & 72 & 13.00 & 3.05 & 134 & 0.857 & 0.393 & 0.005 & \\
\cline { 2 - 11 } & Boy & 64 & 12.55 & 3.11 & 134 & & & & \\
\hline $\begin{array}{l}\text { Resistance } \\
\text { to premature } \\
\text { closure }\end{array}$ & Goy & 64 & 12.38 & 3.80 & 134 & -0.400 & 0.690 & 0.001 & \\
\hline \multirow{2}{*}{\begin{tabular}{l} 
Total creativity \\
\cline { 2 - 11 }
\end{tabular}} & Girl & 72 & 23.89 & 4.89 & 134 & 0.373 & 0.710 & 0.001 & \\
\cline { 2 - 11 } & Boy & 64 & 23.53 & 6.18 & 134 & & & & \\
\hline
\end{tabular}

${ }^{\star} p<.05$. 


\section{Conclusions, discussions, and recommendations}

The results and discussion of the data collected from this study was designed to follow up whether or not the CAs showed significant changes in the 9th and 12th grades are presented below in accordance with the purposes of the study.

It was determined that fluency and RPMC scores of the adolescents in the 9th grade were significantly different from their fluency and RPMC scores in the 12th grade and this differentiation was in favor of their fluency and RPMC scores in the 9th grade. When the results of other studies were examined, it was seen that they supported these results. In a cross-sectional examining the DC at the level of the grades, it was determined that the fluency scores were the highest in the 6th, 7th and 9th grades, and decreased in the 10th and 11th grades, and the RPMC scores increased from the 1st grade to 9th grade, were the highest in the 9th grade, and decreased in the 10th and 11th grades (Köksal Akyol \& Salı, 2016). The decrease in some creativity subscales scores may be associated with the characteristics of the age period. As a matter of fact, it is stated that adolescents deal with the choice of profession, and university entrance in the age period of 17-19 years and this is among the reasons interrupting the creativity (Smutny, 1993; Ataman, 1993). In our country, especially this age is a period in which adolescents put everything aside and prepare only for university entrance exam and study intensively.

The elaboration scores in the 9th grade differed from the elaboration scores in the 12th grade in a statistically significant manner and this differentiation was in favor of the elaboration scores in the 12th grade. Similar results were found in the literature. As a result of the study conducted by Elif Ceylan (2008) to examine creativity levels of 5-6 year-old preschool children based on cognitive tempo, it was determined that while the age of the children caused a statistically significant difference between detailing (elaboration) scores, detailing (elaboration) scores of 6 year-old children were significantly higher than those of 5 year old children. In the study by Zeynep Atay (2009), it was found that there was a significant correlation between the ages of children and their elaboration scores and detailing (elaboration) scores were significantly higher in 6 year-old children compared to 5 year-old children. Another study yielded similar results. Although this study examined creavitity of the 9th-12th grade students' creavitity, and this age group's creativity is different from the creativity of the preschoolers aged 5-6, but the study gives an idea that a significant difference has emerged with age. Therefore, this comparison should be considered as important. As a result of the research conducted by Sietske W. Kleibeuker, Carsten de Dreu and Eveline Crone (2013), creativity scores increased with age supported this result. Even in the visual spatial field, 15-16 year olds performed better than 12-13 year olds. In another LS, it was found that creativity scores increased significantly from 4th grade to 6th grade (Lau \& Cheung, 2010). As a result of the study by Amy F. Claxton, Tammy C. Pannells, and Paul A. Rhoads (2005, p. 332), detailing (elaboration) scores were observed to increase gradually in the 4th, 6th and 9th grades. In the study by Füsun G. Alacapınar (2013), it was determined that fluency, flexibility, originality, detailing (elaboration) and total scores increased from 3rd grade to 5th grade (Alacapinar, 2013). As the grade level rises, the age increases and this result can be interpreted as the fact that as the grade level increases, detailing (elaboration) enhanced. In 
a cross-sectional study conducted at the level of the grades, it was found that the elaboration scores was the highest in the 5th, 6th, 9th, and 10th grades (Köksal Akyol \& Sal1, 2016). There was no significant difference in the scores of originality and ATs subscales of the creativity and TC score. Although there was no significant difference, these results indicated that the fluency and RPMC scores of the adolescents in the 9th grade decreased in the 12th grade; their elaboration scores in the 9th grade increased in the 12th grade; their scores of originality and the ATs subscales and their TC scores did not change in both applications.

It was found that the ATs scores of the adolescents participating in the study in the 9th grade differed according to gender and this differentiation was in favor of the scores of the FAs. No significant differentiation was observed in the scores of fluency, originality, elaboration, and RPMC subscales and TC score based on gender. Although there was no significant difference, the mean scores of the MAs were higher in fluency, originality, resistance to premature closure, and subscales; whereas, the FAs had higher elaboration score and TC score. As a result of the study by Paula Y. Mullineaux and Lisabeth F. DiLalla (2009), they stated that elaboration scores of 10-15 year-old girls were higher than boys' elaboration scores and girls' drawings were better and more innovative. In their study, Aysel Köksal Akyol and Güneş Salı (2016) found that there was a significant difference between the grade levels in terms of ATs and the creativity mean score of the girls attending high school was higher than boys.

It was determined that the fluency scores of the adolescents in the 12th grade differed according to gender and this differentiation was in favor of the scores of the MAs. In their study, Köksal Akyol and Salı (2016), found that there was a significant difference in fluency scores only in favor of girls attending kindergarten. Even though there was no significant difference, fluency mean scores of girls in the first and second levels of primary school and in high school were higher than those of boys. There was no significant difference in scores of originality, ATs, elaboration, and RPMC subscales and TC score. Although there was no significant difference, the mean scores of MAs were higher in the originality subscale; whereas the mean scores of the FAs were higher in the ATs and elaboration subscales.

When the scores obtained in the 9th and 12th grade were examined in terms of gender, it was found that the fluency, originality and RPMC scores of the MAs in the 9th grade were higher than the scores of the FAs and their fluency and originality scores in the 12th grade were also higher than the FAs. On the other hand, while the ATs, elaboration, and TC scores of the FAs in the 9th grade were higher than the scores of MAs and their scores of ATs and elaboration in the 12th grade were higher than the MAs. As a result, it can be asserted that while the MAs maintained their high fluency and originality scores, the FAs maintained their high ATs and elaboration scores in both applications. Fluency is the ability to produce a large number of solutions to a problem encountered, and originality is to be unusual, to produce unusual solutions to the problem. The abstraction of the titles means being able to express what is important, to capture the essence of the subject, and enrichment means diligence and refinement (R. P. Rein \& R. Rein, 2000). According to this, it can be said that male adolescents can produce more and more unusual solutions and FAs give more attention to detail.

Creativity has an important place in the rapid growth of science and technology in today's globalized world. Creative impulse is an important factor that helps in scientific progress. The countries that define and know how to develop and promote the CRP in their youth will find 
themselves in a very advantageous position. Creative adolescents are a national resource and should be identified at the school stage and allowed to follow the field of activity in which they are able to show their talents (Hanarick \& Neeraj, 2018).

The development of creative skills and competence is a key area that requires further research. Starting from this point of view, some suggestions can be made for future studies; studies on examination of the creativity of parents and teachers in addition to the creativity of children as well as comparison of creativities of parents and children and creativities of teachers and children can be conducted. Experimental studies using different methods and techniques to develop children's creativity can be planned. Data collection tools can be developed to evaluate children's creativity according to different age groups or a study adaptation to Turkish can be conducted.

\section{References}

Alacapinar, F. G. (2013). Grade level and creativity. Eurasian Journal of Educational Research, 50, 247-266. Aral, N. (2000). Yaratıcılık ve Zeka. Çağdaş Eğitim, 57, 30-31.

Aslan, E. (2001). Torrance Yaratıcı Düşünce Testi’nin Türkçe Versiyonu. Marmara Üniversitesi Atatürk Eğitim Fakültesi Eğitim Bilimleri Dergisi, 14, 19-40.

Ataman, A. (1993). Eğitim Sürecinde Yaratıcılık, in A. Ataman (Ed.), Yaratıcılık ve Eğitim (pp. 105-124). Ankara: Türk Eğitim Derneği.

Atay, Z. (2009). Okul Öncesi Eğitim Kurumlarına Devam Eden 5-6 Öğrencilerinin Yaş, Cinsiyet ve Ebeveyn Eğitim Durumlarına Göre İncelenmesi: Ereğli örneği (Master's Thesis). Selçuk University, Konya, Turkey [unpublished source].

Atkıncı, H. (2001). İlköğretim Birinci Kademe Eğitim Programlarının Yaratıı Düşünmenin Gelişmesine Etkileri (Master's Thesis). Çanakkale Onsekiz Mart University, Çanakkale, Turkey [unpublished source].

Beetlestone, F. (1998). Creative children, imaginative teaching. Series: Enriching the primary curriculum: child, teacher, context. J. Moyles (Series Ed.). Buckingham: Open University Press.

Bunge, S. A., \& Wright, S. B. (2007). Neurodevelopmental changes in working memory and cognitive control. Current Opinion in Neurobiology, 17, 243-250. https://doi.org/10.1016/j.conb.2007.02.005

Büyüköztürk, Ş. (2007). Veri Analizi El Kitabı. Ankara: Pegem Yayıncılık.

Can Yaşar, M. (2009). Anasınııına Devam Eden Altı Yaş Çocuklarının Yaratıcı Düşünme Becerilerine Drama Eğitiminin Etkisinin Incelenmesi (PhD Thesis). Ankara University Institute of Science and Technology, Ankara, Turkey [unpublished source].

Ceylan, E. (2008). Okulöncesi Eğitime Devam Eden 5-6 Yaş Çocuklarının Bilişsel Tempoya Göre Yaratıcılık Düzeylerinin İncelenmesi (Master's Thesis). Selçuk University, Konya, Turkey [unpublished source].

Claxton, A. F., Pannells, T. C., \& Rhoads, P. A. (2005). Developmental trends in the creativity of school-age children. Creativity Research Journal, 17(4), 327-335. https://doi.org/10.1207/s15326934crj1704_4

Craft, A. (2003). Creative thinking in the early years of education. Early Years: An International Journal of Research and Development, 23(2), 147-157. https://doi.org/10.1080/09575140303105

Crone, E. A., \& Dahl, R. E. (2012). Understanding adolescence as a period of social-affective engagement and goal flexibility. Nature Reviews: Neuroscience, 13, 636-650.

https://doi.org/10.1038/nrn3313 
Cropley, A. J. (1997). Fostering creativity in the classroom: general principles, in M. A. Runco (Ed.), The creativity research handbook (pp. 83-114). Vol. 1. Cresskill, NJ: Hampton Press.

Csikszentmihalyi, M. (1996). Creativity: the psychology of discovery and invention. New York: HarperPerennial, ModernClassics.

Çetingöz, D. (2002). Okulöncesi Eğitimi Öğretmenliği Öğrencilerinin Yaratıcı Düşünme Becerilerinin Gelişiminin İncelenmesi (Master’s Thesis). Dokuz Eylül University, İzmir, Turkey [unpublished source].

Diamond, A., Kirkham, N., \& Amso, D. (2002). Conditions under which young children can hold two rules in mind and inhibit a prepotent response. Developmental Psychology, 38(3), 352-362. https://doi.org/10.1037/0012-1649.38.3.352

Doğan, N. (2005). Yaratıcı Düşünme ve Yaratıcılık, in Ö. Demirel (Ed.), Eğitimde Yeni Yönelimler (167198). Ankara: Pegem Akademi. https://doi.org/10.14527/9789758792740.10

Dumontheil, I., Houlton, R., Christoff, K., \& Blakemore, S.-J. (2010). Development of relational reasoning during adolescence. Developmental Science, 13(6), 15-24. https://doi.org/10.1111/j.1467-7687.2010.01014.x

Erlendsson, J. (1999). The role of creativity. Retrieved from http://www.hi.is/ joner/eaps/cq_cr04.htm

Gardner, H. (1993). Creating minds: an anatomy of creativity seen through the lives of Freud, Einstein, Picasso, Stravinsky, Eliot, Graham, and Gandhi. New York: Basic Books.

Gartenhaus, A. R. (2000). Yaratıcı Ddüşünme ve Müzeler. B. Onur (Ed.). Ankara: Ankara Üniversitesi Çocuk Kültürü Araştırma ve Uygulama Merkezi Yayınları.

Getzels, J. W., \& Jackson, Ph. W. (1962). Creativity and intelligence: explorations with gifted students. New York: John Wiley \& Sons, Inc. https://doi.org/10.2307/40223437

Guilford, J. P. (1950). Creativity. American Psychologist, 5(9), 444-454. https://doi.org/10.1037/h0063487

Güvenç, B. (1993). Yaratıcılığın Toplumsal ve Kültürel Boyutları, in A. Ataman (Ed.), Yaratıcılık ve Eğitim (pp. 129-136). Ankara: Türk Eğitim Derneği.

Hanarick, S., \& Neeraj, M. (2018). A study of creattvity among adolescent students. Retrieved from file://C:/Users/14387/AppData/Local/Microsoft/Windows/INetCache/IE/0OJEYRWB/467-Article\%20Text-1117-1-10-20180625.pdf

Huizinga, M., \& Molen, van der M. W. (2007). Age-Group differences in set-switching and set-maintenance on the wisconsin card sorting task. Devevopmental Neuropsychology, 31(2), 193-215. https:// doi.org/10.1080/87565640701190817

Hurlock, E. B. (1978). Child development. New York: Mcgraw-Hill.

Im, H., Hokanson, B., \& Johnson, K. K. P. (2015). Teaching creative thinking skills: a longitudinal study. Clothing and Textiles Research Journal, 33(2), 129-142. https://doi.org/10.1177/0887302X15569010

Isenberg, J. P., \& Renck Jalongo, M. (1993). Creative expression and play in the early childhood. New York: Macmillan Publishing Company.

Johnson, C., \& Wilbrecht, L. (2011). Juvenile mice show greater flexibility in multiple choice reversal learning than adults. Developmental Cognitive Neuroscience, 1, 540-551. https://doi.org/10.1016/j.dcn.2011.05.008

Jolles, D. D., \& Crone, E. A. (2012). Training the developing brain: a neurocognitive perspective. Frontiers in Human Neuroscience, 6, 1-13. https://doi.org/10.3389/fnhum.2012.00076

Karasar, N. (2009). Bilimsel Araştırma Yöntemi. Ankara: Nobel Dağıtım.

Karbach, J., \& Kray, J. (2009). How Useful is Executive Control Training? Age differences in near and far transfer of task-switching training. Developmental Science, 12(6), 978-990. https://doi.org/10.1111/j.1467-7687.2009.00846.x

Kayar, O. (2016). Ergenlerde Algılanan Ebevenylik Stilleri, Özerklik ve Yaratıcılık Arasındaki İlişkiler (Master's Thesis). Bolu Abant Izzet Baysal University, Bolu, Turkey [unpublished source]. 
Kleibeuker, S. W., Dreu, De C. K. W., \& Crone, E. A. (2016). Creativity development in adolescence: insight from behavior, brain, and training studies. New Directions for Child and Adolescent Development, 151, 73-84. https://doi.org/10.1002/cad.20148

Kleibeuker, S. W., Dreu, De C. K. W., \& Crone, E. A. (2013). The development of creative cognition across adolescence: distinct trajectories for insight and divergent thinking. Developmental Science, 16(1), 2-12. https://doi.org/10.1111/j.1467-7687.2012.01176.x

Kleibeuker, S. W., Stevenson, C. E., Aar, van der L., Overgaauw, S., Duijvenvoorde, van A. C., \& Crone, E. A. (2017). Training in the Adolescent Brain: An fMRI training study on divergent thinking. Developmental Psychology, 53(2), 353-365. https://doi.org/10.1037/dev0000239

Klingberg, T. (2010). Training and plasticity of working memory. Trends in Cognitive Sciences, 14(7), 317-324. https://doi.org/10.1016/j.tics.2010.05.002

Köksal Akyol, A., \& Salı, G. (2016). An investigation of creativity among children in kindergartens, primary, middle and high schools. Journal of Theoretical Educational Science, 9(3), 379-399. https://doi.org/10.5578/keg.9786

Laius, A., \& Rannikmae, M. (2005). The influence of social 1ssue-based science teaching on students' creative thinking. Science Educational International, 14(4), 21-28.

Lau, S., \& Cheung, P. Ch. (2010). Development trends of creativity: what twists of turn do boys and girls take at different grades? Creativity Research Journal, 22(3), 329-336. https://doi.org/10.1080/10400419.2010.503543

Lowden, M. (1989). Dancing to learn: dance as a strategy in the primary school curriculum. London, New York: The Falmer Press.

Lubart, T. I. (1994). Creativity, in R. J. Sternberg (Ed.), Thinking and problem solving (pp. 290-332). Series: Handbook of Perception and Cognition. E. C. Carterette \& M. P. Friedman (Series Eds.). San Diego: Academic Press. https://doi.org/10.1016/B978-0-08-057299-4.50016-5

Matud, M. P., Rodríguez, C., \& Grande, J. (2007). Gender differences in creative thinking. Personality and Individual Differences, 43(5), 1137-1147. https://doi.org/10.1016/j.paid.2007.03.006

McGregor, G. D. Jr. (2001). Creative thinking instruction for a college study skills program: a case study (PhD Thesis). Baylor University, Texas, United States [unpublished source].

Mullineaux, P. Y., \& DiLalla, L. F. (2009). Preschool pretend play behaviors and early adolescent creativity. Journal of Creative Behavior, 43(1), 41-57. https://doi.org/10.1002/j.2162-6057.2009.tb01305.x

Öncü, T. (2003). Torrance Yaratıcı Düşünme Testleri-Şekil Testi Aracılığıyla 12-14 Yaşları Arasındaki Ēocukların Yaratıcılık Düzeylerinin Yaş ve Cinsiyete Göre Karşılaştırılması. Ankara Üniversitesi Dil ve Tarih Coğrafya Fakültesi Dergisi, 43(1), 221-237. https://doi.org/10.1501/Dtcfder_0000000164

Prentice, R., Matthews, J., \& Taylor, H. (2003). Creative development: learning and the arts, in J. Riley (Ed.), Learning in the Early Years: A Guide for Teachers of Children 3-7 (pp. 185-218). London: Paul Chapman Publishing.

Qin, Y., Carter, C. S., Silk, E. M., Stenger, V. A., Fissell, K., Goode, A., \& Anderson, J. R. (2004). The change of the brain activation patterns as children learn algebra equation solving. Proceedings of the National Academy of Sciences of the United States of America, 101(15), 5686-5691. https://doi.org/10.1073/pnas.0401227101

Rein, R. P., \& Rein, R. (2000). Çocuğunuzun Beceri ve Yeteneklerini Nasıl Geliştirebilirsiniz? İstanbul: Ya-pa Yayınları.

Reza Tamannaeifar, M., \& Motaghedifard, M. (2014). Subjective well-being and its subscales among students: the study of role of creativity and self-efficacy. Thinking Skills and Creativity, 12, 37-42. https://doi.org/10.1016/j.tsc.2013.12.003

Roberts, L. (2003). Creativity. Tech Directions, 63(3), 12-23. https://doi.org/10.1111/1467-8691.00269

Rothenberg, A. (2016). Adolescence and creativity. Psychology today. Retrieved from https://www.psychologytoday.com/intl/blog/creative-explorations/201611/adolescence-and-creativity 
Rothenberg, A. (1990). Creativity in adolescence. Psychiatric Clinics of North America, 13(3), 415-434. https://doi.org/10.1016/S0193-953X(18)30351-4

Rudowicz, E., Kitto, E., \& Lok, D. (1992, 24-27 July). The Neglected Part of Giftedness: Creativity. In Proceedings of the Second Asian Conference Giftedness (pp. 381-390). Second Asian Conference on Giftedness 1992. Taipei, Taiwan, China.

Runco, M. A., Acar, S., \& Cayirdag, N. (2017). A closer look at the creativity gap and why students are less creative at school than outside of school. Thinking Skills and Creativity, 24, 242-249. https://doi.org/10.1016/j.tsc.2017.04.003

Sall, G. (2015). A longitudinal study on the development of creativity in children. The Antropologist, 20(1-2), 93-100. https://doi.org/10.1080/09720073.2015.11891728

Salı, G., \& Köksal Akyol, A. (2015). Creativity of preschool and elementary school teachers and their students. Perceptual \& Motor Skills: Learning and Memory, 121(3), 759-765. https://doi.org/10.2466/22.PMS.121c27x2

San, İ. (1985). Sanat ve Eğitim. Ankara: Ankara Üniversitesi.

San, İ. (1977). Sanatsal Yaratma ve Çocukta Yaratıcılık. Ankara: Türkiye İş Bankası Kültür Yayınları.

San, İ. (2004a). Sanat ve Eğitim: Yaratıcılık, Temel Sanat Kuramları, Sanat Eleştirisi Yaklaşımları. Ankara: Ütopya.

San, İ. (2004b). Yaratıcılıkta Temel Kavramlar, in A. Öztürk (Ed.), Çocukta Yaratıcılık ve Drama (pp. 1-14). Anadolu Üniversitesi Yayını: Eskişehir.

Smutny, J. F. (1993, 8-13 August). Talented education. 10th Biennial World Council for Gifted and Talented Children World Conference 1993. Toronto, Canada [unpublished source].

Sonmaz, S. (2002). Problem Çözme Becerisi ile Yaratıcılık ve Zeka Arasındaki İlişkinin İncelenmesi (PhD Thesis). Marmara University, İstanbul, Turkey [unpublished source].

Sternberg, R. J. (2005). Creativity or creativities? International Journal of Human-Computer Studies, 63(4-5), 370-382. https://doi.org/10.1016/j.ijhcs.2005.04.003

Sternberg, R. J., \& Lubart, T. I. (1995). Defying the crowd: cultivating creativity in a culture of conformity. New York, NY: The Free Press.

Stevenson, C. E., Kleibeuker, S. W., Dreu, de C. K. W., \& Crone, E. A. (2014). Training creative cognition: adolescence as a flexible period for improving creativity. Frontiers in Human Neuroscience, 8 , 1-16. https://doi.org/10.3389/fnhum.2014.00827

Tegano, D. W., Moran, III J. D., \& Sawyers, J. K. (1991). Creativity in early childhood classrooms. Series: Nea Early Childhood Education Series. Washington, DC: National Education Association.

Torrance, E. P. (1995). Why fly? A philosophy of creativity. Series: Creativity Research. M. A. Runco (Series Ed.). Norwood, NJ: Ablex Publishing Corporation.

Torrance, E. P., \& Goff, K. (1989). A quiet revolution. Journal of Creative Behavior, 23(2), 136-145. https://doi.org/10.1002/j.2162-6057.1989.tb00683.x

Üstündağ, T. (2014). Yaratıcıliğa Yolculuk. Baskı. Ankara: Pegem Akademi.

Yaman, S., \& Yalçın, N. (2005). Fen Eğitiminde Probleme Dayalı Öğrenme Yaklaşımının Problem Çözme ve Öz-Yeterlik İnanç Düzeylerinin Gelişimine Etkisi. Hacettepe Üniversitesi Eğitim Fakültesi Dergisi, 29, 229-236.

Yeh, Y. C., Yeh, Y. H., Li, M. L., \& Pen, Y. Y. (2006). An action research in employing creative drama instruction to improve preschoolers' creativity. Journal of Taiwan Normal University Education, 51, 1-27.

Yüksel, T. (2016). Ortaokul 5. Sinıf Türkçe Derslerinde Uygulanan Yaratıcı Yazma Etkinliklerinin Öğrencilerin Yazmaya Yönelik Tutumlarına ve Sözel Yaratıcılıklarına Etkisinin İncelenmesi (Master’s Thesis). Akdeniz University, Antalya, Turkey [unpublished source].

Zinke, K., Einert, M., Pfennig, L., \& Kliegel, M. (2012). Plasticity of executive control through task switching training in adolescents. Frontiers in Human Neuroscience, 6, 1-15.

https://doi.org/10.3389/fnhum.2012.00041 


\title{
IX IR XII KLASIŲ PAAUGLIŲ KÜRYBIŠKUMO PLĖTROS ANALIZĖ: KETVERIŲ METŲ TRUKMĖS ILGALAIKIS TYRIMAS
}

\author{
Güneş SALI
}

\section{Santrauka}

Šis ilgalaikis tyrimas buvo atliktas siekiant išsiaiškinti, ar IX ir XII klasėse atsiskleidè paauglių kūrybiškumo pokyčiai. Šiame tyrime buvo panaudotas koreliacinis atrankos modelis, kuris yra vienas iš aprašomųjų metodų. Imties grupę iš viso sudare 145 (76 mergaitès, 69 berniukai) paaugliai, kurie 2014-2015 mokslo metais lankẻ Jozgato vidurinę mokyklą, esančią Jozgato centre (Turkija), ir buvo atrinkti iš IX klasių, taikant atsitiktinès atrankos metodą. Atrinktajai grupei pasiekus XII klasę, paauglių skaičius sumažèjo iki 136 (72 mergaitès, 64 berniukai). Buvo analizuota remiantis duomenimis, surinktais iš 136 paauglių, kuriuos buvo galima tirti, jiems mokantis XII klasejje. Bendrąja informacijos forma ir Torrance'o kūrybinio mąstymo testu (pav. A) buvo naudojamasi kaip duomenų rinkimo priemoné. Analizuojant duomenis, buvo taikomas aprašomasis statistinis dažnis, porinis atrankos $t$ kriterijus pakartotiniams matavimams ir kriterijus - nesusijusiems matavimams. Atlikus tyrimą buvo nustatyta, kad tų paauglių, kurie dalyvavo tyrime, besimokydami IX klasejje, sklandumo ịverčiai reikšmingai skyrėsi nuo jų sklandumo ịverčių ir veiksmų nutraukimo nebaigus užduoties įverčių XII klasèje, o ši diferenciacija buvo palanki sklandumo ir veiksmų nutraukimo nebaigus užduoties ịverčiams IX klasẻje. Jų tobulejjimo įverčių IX klasẻje statistiškai reikšmingai skyrèsi nuo tobulejjimo įverčių XII klasėje, o ši diferenciacija buvo palanki jų tobulejjimo lygiui XII klasèje $(p<, 05)$. Abstraktumo ịverčiai IX klasẻje buvo palankūs moteriškosios lyties paaugliams, o XII klasės moksleivių sklandumo ịverčiai buvo palankūs vyriškosios lyties paaugliams, ir tai statistiškai skyrėsi pagal lyti $(p<, 05)$.

Reikšminiai žodžiai: paauglys (-è), kūrybiškumas, kūrybiškumas ir klasès lygis, kūrybiškumas ir lytis, ilgalaikis tyrimas. 